\title{
Introducing Testimonios: A Collection of Stories of Latinx and Hispanic Mathematicians
}

\section{Pamela E. Harris, Alicia Prieto-Langarica, Vanessa Rivera Quiñones, Luis Sordo Vieira, Rosaura Uscanga, and Andrés R. Vindas Meléndez}

\begin{abstract}
"Mathematics is not created nor discovered in a vacuum. Inherent to mathematical progress is the stories of the people behind it." - Lathisms Team
\end{abstract}

\section{Introduction}

The year 2020 marked the fifth anniversary of Lathisms: Latinxs and Hispanics in the Mathematical Sciences (lathisms.org). To celebrate this milestone, we are excited to announce our upcoming book, titled Testimonios: Stories of Latinx and Hispanic Mathematicians. In short, this book is a love letter to our community.

Pamela E. Harris is an associate professor of mathematics at Williams College. Her email address is pame1a.e.harris@wi 11iams. edu.

Alicia Prieto-Langarica is a professor of mathematics at Youngstown State University. Her email address is aprietolangarica@ysu.edu.

Vanessa Rivera Quiñones is a data science consultant and instructor. Her email address is vriveraq.phd@gmai1.com.

Luis Sordo Vieira is a research assistant professor in the department of medicine at the University of Florida. His email address is 1uis.sordovieira amedicine.uf1.edu.

Rosaura Uscanga is an assistant professor of mathematics at Mercy College. Her email address is ruscanga@mercy.edu.

Andrés R. Vindas Meléndez is an NSF postdoctoral fellow at UC Berkeley and a postdoctoral fellow at MSRI. His email address is avindas@msri .org.

Communicated by Notices Associate Editor Stephan Ramon Garcia.

For permission to reprint this article, please contact:

reprint-permission@ams.org.

DOI: https://doi.org/10.1090/noti2334
The testimonios ${ }^{1}$ in this collection have truly inspired us. Readers will be energized by the stories of outstanding researchers and educators; these mathematicians have overcome challenges (both personal and systemic) and their stories depict their resilience and devotion to the field of mathematics. In addition to reading about the successes of the mathematicians featured, we challenge all readers within the mathematical community to pay attention to the struggles, inequities, and problems that we, as a community and as individuals, should strive to resolve in order to improve the experience of those marginalized in mathematics, including Latinxs and Hispanics.

Our greatest hope is that reading the testimonios of inspiring mathematicians helps further the growth and the brilliance of the Latinx and Hispanic community. We also hope that younger generations of mathematicians see themselves reflected in these stories, and learn that we all stand on the shoulders of giants.

We present the testimonio of Dr. James A. Mendoza Álvarez, a mathematics education researcher who works at the University of Texas at Arlington. Dr. Álvarez's testimonio begins with the story of his mother, Olga Mendoza, whose life takes us through a time in the 20th century when signs stating "Mexicans not allowed" were commonplace in Texas. Olga's struggles, wisdom, and influence not only illustrate the plight of people of Mexican descent, but have also been a major driving force in Dr. Álvarez's

${ }^{1}$ A testimonio is a first-person narrative. 
life and in his professional trajectory. After his testimonio, Dr. Álvarez gives advice for those of us within academia whose work aims to address the underrepresentation of Latinxs and Hispanics in the mathematical sciences.

\section{Dr. James A. Mendoza Álvarez's Testimonio}

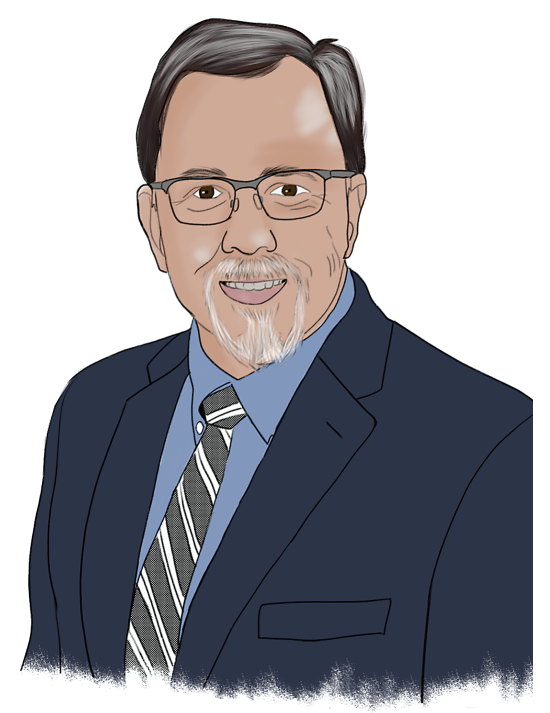

Figure 1. Dr. James A. Mendoza Álvarez.

2.1. Olga's story. My mother, Olga Mendoza, grew up in a small community formed around the turn of the 20th century as a "company town." The company produced large clay sewer pipes in the town of Saspamco, Texas, which is actually an acronym for San Antonio Sewage Pipe and Manufacturing Company. Before my grandfather, Federico Mendoza, was murdered in 1939, he worked at the company, and so did several of my great uncles and later so did my brothers. This town was (and still is) comprised of more than 95\% Hispanic people of different backgrounds. That is, some had been in the area when Texas was part of Spain and Mexico, while others (like my great-grandparents) had come to the area in the 1880s and 1890 s, and the remainder were those who had left Mexico during the Mexican revolution in the 1910s.

My mom went to school in Saspamco through the eighth grade. However, high school grades in Saspamco were not accredited by the state of Texas. So students who wanted to earn a valid high school diploma had to go ten miles away to attend school in the nearby town of Floresville. During this time of the Great Depression, Maria (Mary) DeAnda, my widowed grandmother, raised poultry and milked cows to support my mother and her brother. This brought enough money to get by, but not enough to afford to pay someone to give Mom a ride to get to high school every day. So at the age of 12, my mom moved to live with her aunt and uncle in South Texas so that she could attend ninth grade at an accredited high school.

The next year, she returned to the farm near Saspamco because Grandma had found a neighbor in Saspamco who worked in Floresville who agreed to charge her $\$ 3$ per week to take mom to and from school. However, the $\$ 3$ a week charge only paid for transportation for Monday through Thursday and Grandma could not afford the additional cost for transportation on Friday. Luckily, Ms. Wiseman, a caring teacher, noticed that my mom was an excellent student, but that she missed school every Friday. Asking her about this and learning of the financial hardship to attend school, Ms. Wiseman generously worked out a plan with my grandma to have Mom stay in town with her each week. This way, Mom could walk to school daily rather than missing one school day per week. Ms. Wiseman provided these accommodations at no cost to my family.

Generous people, like Ms. Wiseman, made it possible for my mom to continue her education; an education which proved to benefit future generations, including me. Yet other people, like Mom's Algebra I teacher, acted in an opposite manner. Mom recalls being the only MexicanAmerican in the class and also the only student who did not receive a textbook from him! Needless to say, my mom did not have a great mathematics background.

Sadly, such discriminatory experiences were not isolated incidents and they affected many within our family. Mom was not allowed into the pool at Landa Park in New Braunfels, Texas, on her high school senior trip because Mexicans were not allowed in the pool; my grandfather was fired from a job in Sugarland, Texas, when the foreman realized he was Mexican-American; as the best students in their Spanish class at Texas A \& I College (now Texas A \& $M$ Kingsville), Mom and another classmate were invited by their professor to eat at the famous Kings Inn and the professor had to ask special permission for Mom to enter because Mexicans were not allowed in; professors at different institutions would routinely give C's to my mom, her cousins, and other Hispanic students regardless of their academic performance.

Being discriminated against for having an accent, for having brown skin, and for being economically disadvantaged shaped the way my mom decided to raise my siblings and me. This in turn greatly affected our drive to strive for excellence as a way to mitigate expected, or unexpected, discriminatory practices that would surely come our way.

In 1955, Mom returned to the community where she grew up as a teacher for Saspamco Independent School District. During this time, Mom had six children (Figure 2).

2.2. James' early years. As the fourth child of six, I vividly recall living in the two-bedroom teacher's cottage. While 


\section{HISTORY}

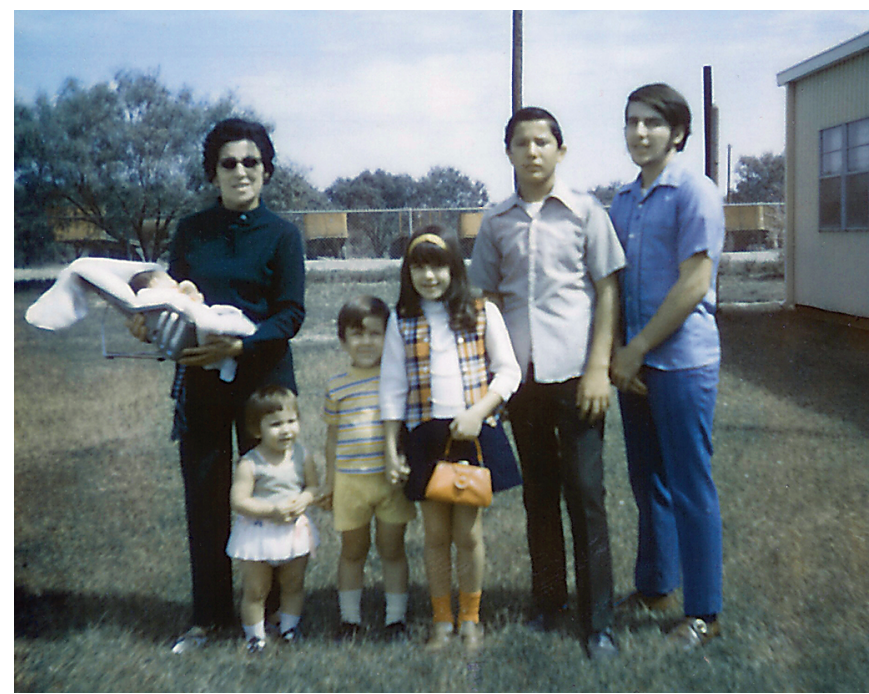

Figure 2. Picture of my grandma with my siblings and me, 1970.

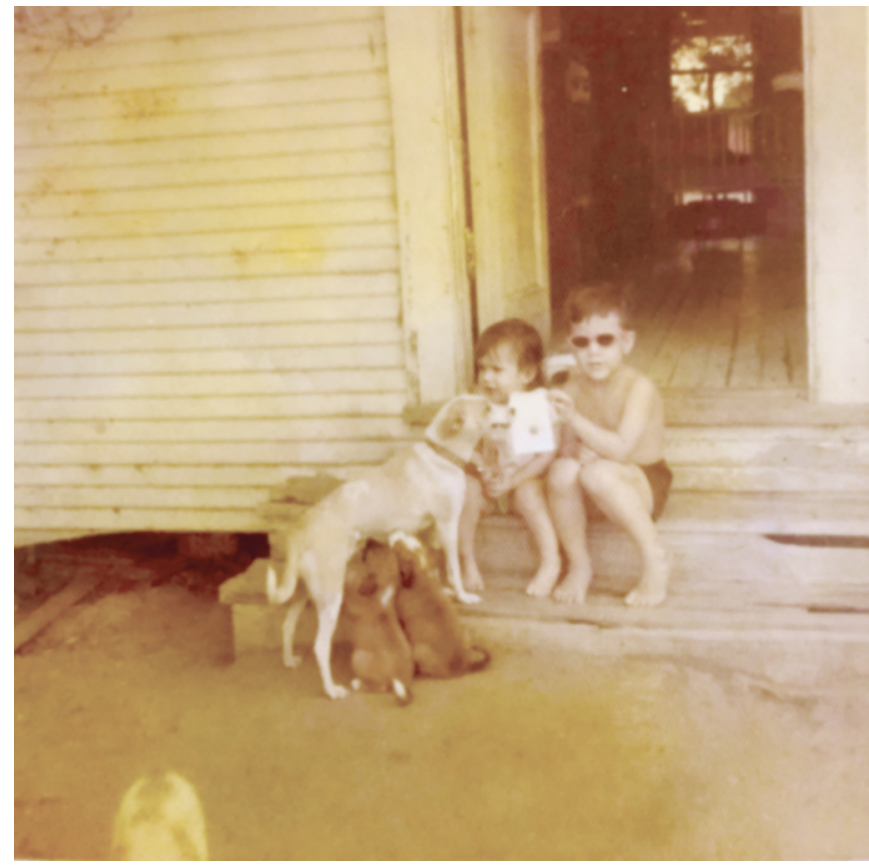

Figure 3. Picture of my little sister Olga (who was appointed judge by the governor of California in 2019) and me at the steps of the teacher's cottage.

the cottage was very affordable, it was not the best living situation for a family of more than seven, especially as it did not have running water in the kitchen.

Whatever challenges this living arrangement posed, I grew up on the idea of "la ropa sucia se lava en casa," which translates to "not airing one's dirty laundry in public." This motto was a way to protect ourselves from being left out given our financial situation and it led to my being very reserved as a child. I did not share personal details with others which, in turn, gave my schoolmates the impression that I was just like everyone else in my class and that I was having the same socioeconomic experiences as them, even if it was not so.

Nonetheless, by the late 1960s, while being at a rural school with only four grades, I was able to freely wander from the cottage to see Mom during the day. Selfidentifying as a "momma's boy," I spent a lot of time in my mom's first grade classroom (Figure 4).

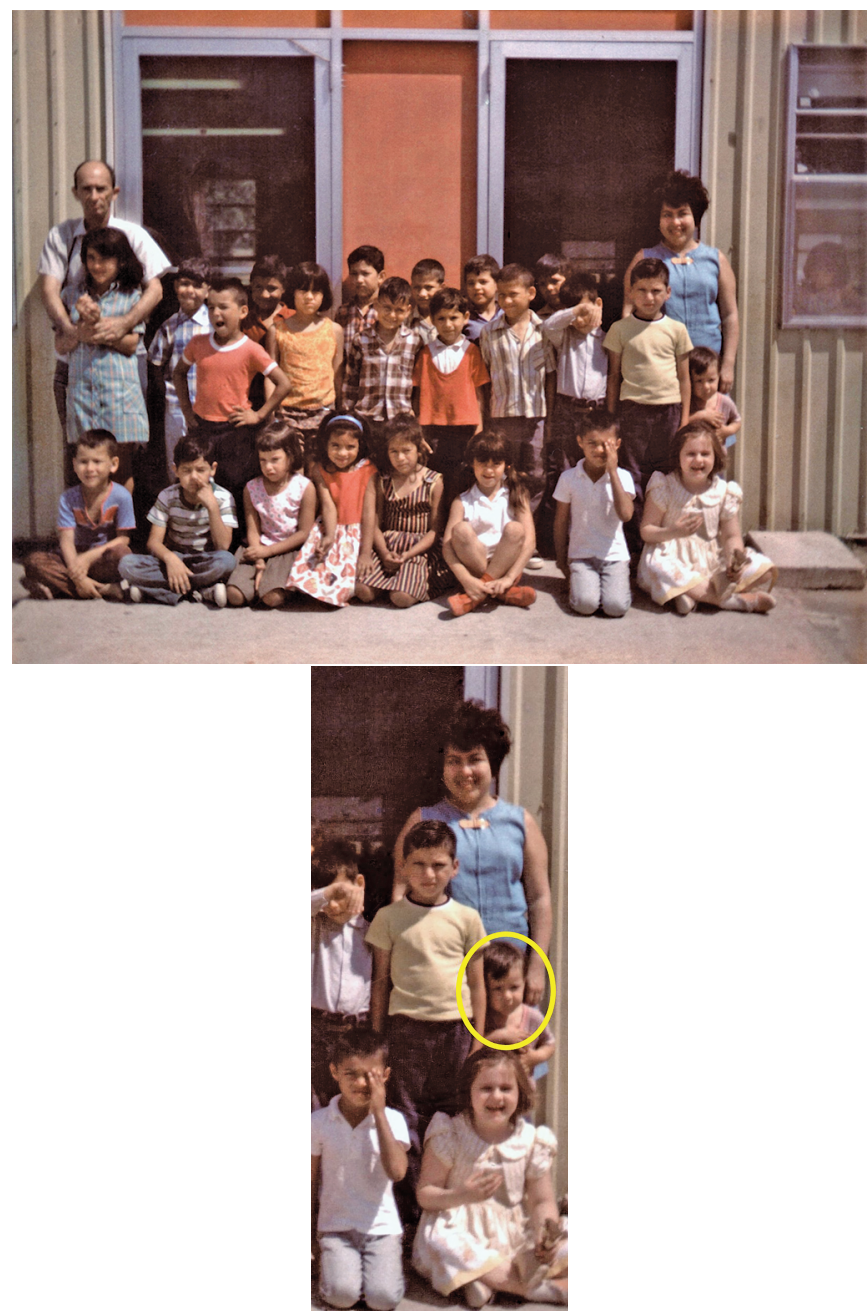

Figure 4. My mother's class in 1968 with me at her skirt.

I cannot remember how I learned to read or add or when I learned about numbers, but I remember being good at it well before I began first grade. In fact, when I was only four or five years old, I would sit at the back of Mom's classroom and follow her math lessons along with all of the other students. From an early age, I would tutor other students, assisting them with their reading and mathematics work. 
By the time I was ready for first grade, Saspamco schools were closed and consolidated with the schools in nearby Floresville. At that time, Saspamco had a population of about 200, while Floresville's population was over 3,000. Around the same time period, my family moved out of the teacher's cottage to live in my great-grandfather's house, which my dad, Jonás Álvarez, had remodeled with his own hands.

I first remember realizing I was good at math in first grade. My mental math skills were very sharp and I had already learned most of what we were learning. This meant that, since the school grouped classes by ability, I was placed in the advanced group. I may not have been conscious of it on my own, but Mom made sure that I understood the responsibility that came from being placed in the advanced group. In a time when my school was about $50-60 \%$ Hispanic, only about five of thirty students in the advanced group were Hispanic.

I later learned that several of the white students in my advanced group were placed there because of their parents' desire to keep them out of classes with large percentages of Hispanics, rather than based on their academic potential and achievement. Mom, a second grade teacher at my school, witnessed the ability grouping process in which these requests were routinely made. Not only this, but she also was subjected to some white parents not wanting their children to be in her classroom because she was Mexican; at that time, there were only a handful of Hispanic teachers in the entire school district.

I distinctly remember being made to feel like an outsider by some of my classmates. To try to fit in, I continued to be quiet and reserved, but I have never forgotten a classmate telling me that my father was a "Meskin lover" because Mom was "Meskin" (a derogatory term for Mexican). Not being white, I could not be part of his group of friends. Remembering my mom's mantra that "education and knowledge" were pathways out of poverty and the only way to combat ignorance, I tried to look past such hurtful statements and focus on learning and being the best student I could be. Not only this, but from my earliest memories, I wanted to be a teacher so that I could help others, just as my mom did. Thus, throughout my childhood, I always felt that I needed to work hard and learn as much as I could; not only for myself, but also for my community.

Always enjoying mathematics, I was fast at arithmetic computations. Ms. Tipton, my third grade math teacher, would give us fifty arithmetic computation problems, including exercises such as multiplying and dividing fourdigit numbers by four-digit numbers, to work each day before starting class. I enjoyed always being the first or second student to finish the computations, and once completing them, I took the opportunity to help others finish their work. One of my earliest joyful moments in my early mathematics education was in fifth grade, when Ms. Higgins taught us about other bases. I was fascinated by working in other bases and I can still recall a paper she handed back to me in which she complimented my work when working in base 5 .

In sixth grade, in addition to reading and numbers, I developed a love for music as I began learning both the piano and trumpet. I enjoyed the piano from the beginning, but not so much the trumpet. I struggled at first, but persisted for two reasons: first, my parents had sacrificed a lot to buy me the trumpet, and, second, because my mother always told me "don't be a quitter." The persistence paid off and I played a solo at the sixth grade concert and was praised by my band director for being the only student who had completed a music theory assignment that would have been challenging for students in a college-level music theory class. In fact, I continued to be a soloist and participated in many honor bands throughout high school. This extended to participating one year in a college marching band as well as a few years in the UT-Austin Mariachi Paredes de Tejastitlán when in graduate school. Also, in high school I was recruited to play the organ at our little church in Saspamco. I found this quite stressful because I am a perfectionist and I disliked making mistakes in public. But, when you're from a small town, then you have to rise to the occasion.

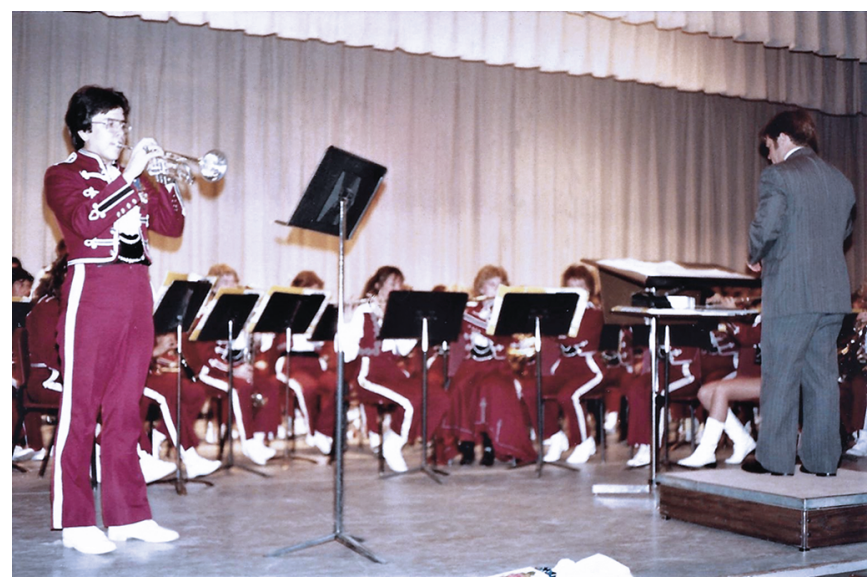

Figure 5. Performing my senior solo in high school (May 1984).

As I moved to junior high, my older sister Mary started high school. Mary would often talk of her perceptions that only white students could be in certain classes and school clubs. Despite her good grades in junior high, the school counselor advised her to become a secretary and take high school classes that would lead to that-it is worth noting that many other Hispanic girls of that generation had also 
received the same advice by this counselor. Mary pushed back and demanded to be allowed to take classes that would allow her to become a teacher, as she also wanted to pursue a career in education like her mother. She won that fight, and I am happy to report that Mary is now Dr. Mary E. Carrasco. She holds an Ed.D. and has taught school for over 30 years.

With my own meeting with the counselor looming, I made up my mind that I would not be subjected to the "othering" my older sister had experienced. As one of the best students in my grade, I was not going to let others limit me. So, I braced myself for the meeting with that same eighth grade counselor. At the meeting, she looked at my grades and scores and said, much to my surprise, "you can be anything you want to be!" As encouraging as this encounter was for me, it made me reflect on how different my sister's experience had been and how back then and even today, the female experience in academia is filled with its own unique challenges. ${ }^{2}$

Miss Escamilla, my only Hispanic mathematics teacher, taught me Algebra I. She was an amazing teacher who guided me in learning more than the planned curriculum so that I could prepare for a mathematics contest in algebra. This was a mathematics subject-based contest sponsored by the Alamo District Council of Teachers of Mathematics in San Antonio for schools in the San Antonio, Texas, region. I placed third in the contest; because we were a small school, we rarely placed at the contest and people took notice. I can still picture her working examples on the board and my excitement to show her my work on problems. Her encouraging and kind words had a profound impact on me. However, I quickly learned that some of my white classmates, when comparing me to high achievers in our school, gossiped that there was no way that I could be smarter than they were because I was "Meskin" and from Saspamco, and now we are at the point where the story repeats itself.

This was one of several discouraging and discriminating events I experienced while in high school, just as my mom experienced in her youth. One very troubling memory comes from my geometry class, where my teacher enforced a policy of not giving a final average grade of more than a $98 \%$. So, even when my average was $100 \%$, she would give me a $98 \%$ on my report card. Aside from the sheer injustice in such a grading scheme, my concern ran deeper. I knew that I could become class valedictorian, an important designation for scholarships to college. Placing a ceiling on my grade only advantaged other students for such a designation. My father called the teacher and asked

\footnotetext{
${ }^{2}$ In fact as a female student, one of the editors of this book had a similar experience thirty years later, where her younger brother was encouraged to pursue higher education while she was advised to become a bilingual secretary.
}

her to give me the grade I earned. She said, "no, because nobody's perfect." I remember my father's response: "well, maybe he's perfect in your imperfection." My father, a former priest, was well versed in logic and philosophy, yet could not get my teacher to understand that a student's average grade in a course tells you more about a teacher's expectations than anything about perfection. Hence, the $98 \%$ grade in geometry remained.

These negative experiences did not end in geometry, as the advanced mathematics teacher routinely told us not to take calculus when we got to college. His reason was personal. He told us that he had done that and failed. One can only guess what little this teacher must have thought of our ability or future trajectories, or whether he understood that he was not really preparing us to be successful in a future calculus course.

Fortunately, neither of these experiences discouraged me. Instead, I worked hard in high school taking advanced classes and learned enough to earn ACT scores that translated to a year's worth of college credits when coupled with College Level Examination Program (CLEP) exams. Furthermore, I became valedictorian of my high school class which entitled me to free tuition at a public university in Texas, and I earned a Presidential Scholarship to East Texas State University (now Texas A \& M Commerce), where I aced my calculus courses despite my high school teacher's discouraging counsel.

\section{Higher Education}

3.1. Undergraduate education. While at East Texas State University, I approached Dr. Stuart Anderson inquiring about completing an honors thesis in mathematics. Dr. Anderson, a topologist, told me he was unsure of what kind of research I could do, as an undergraduate. This led me to work on an honors thesis in physics, my second major.

After beginning the physics honors thesis, I realized that I did not like the particular project I was pursuing. I also calculated that if I did not complete an honors thesis, I could graduate with academic distinction after only completing six semesters. The latter of which would allow me to return closer to home; a great benefit, as I was incredibly homesick. In light of this, I dropped the honors thesis and instead completed independent study courses with Dr. Anderson, who offered these courses so that I could prepare for graduate school in mathematics. ${ }^{3}$

\footnotetext{
${ }^{3}$ Dr. Anderson told me later that he always regretted not being more proactive about finding me a project for a mathematics honors thesis. But, Dr. Anderson's Moore-Method topology course, which he offered on his own time to me and another classmate, provided a strong mathematical foundation for my future graduate studies.
} 


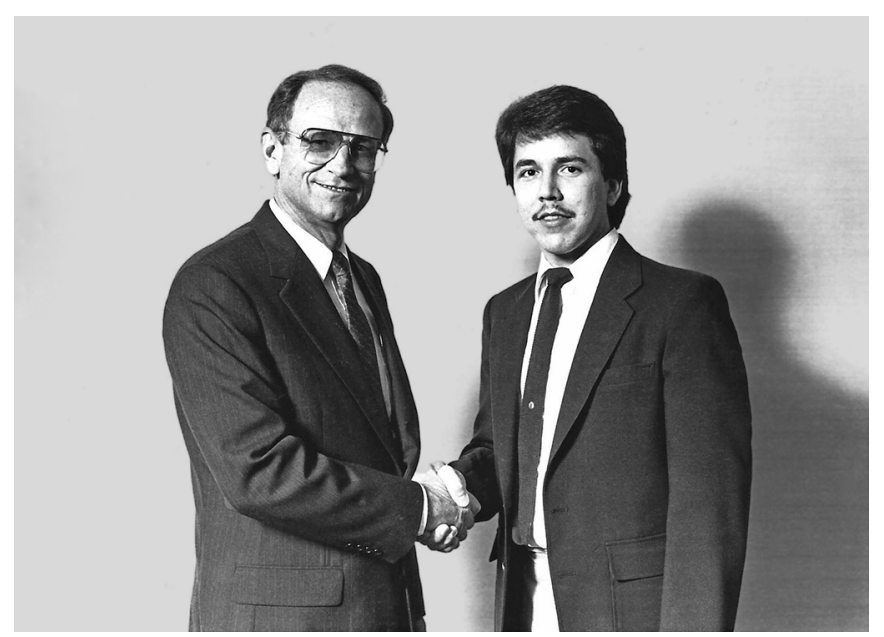

Figure 6. Picture of me in 1987 with Dr. Jerry Morris, President of ETSU, for having been named Outstanding Senior Physics student and for Academic Distinction.

3.2. Graduate education. Having finished my undergraduate degree in three years, I entered graduate school at the University of Texas Austin. Yet, I had not taken an undergraduate real analysis course. Perceiving myself as a highly capable mathematics student, I felt terrible that I had to take undergraduate real analysis when I was a graduate student. My lack of understanding of graduate education in the sciences and not having any role models to assure me that this was okay was disconcerting. I began to question whether I was really graduate school material, while not remembering that I was a 21 -year-old who had opted out of a fourth year of undergraduate studies. Yet, my choices and poor graduate advising made my first few years of graduate school emotionally difficult. For example, I was not advised against taking the second semester of graduate abstract algebra without having had the first semester of the course. Whether such advising was due to plain negligence, or potentially something more problematic, I will never know.

My graduate education was supported through a Graduate Opportunity Fellowship for underrepresented minorities. While it provided enough support so that I could be financially self-sufficient, I felt left out of the group of graduate students who were serving as teaching assistants. On several occasions my fellow classmates clearly equated my being on a Graduate Opportunity Fellowship as meaning that I was not qualified to be in graduate school. Yet, time would prove them wrong since of the approximate 30 students who entered the PhD program in my year, I estimate that only six of us eventually finished the degree.

Preparing for my preliminary exams at UT-Austin was quite stressful. Graduate students had access to copies of old preliminary exams along with recommended resources and books from which to study. However, there was an important book that I did not have and which had been indefinitely checked out of the library. As is still commonplace, the book was too expensive to purchase on a graduate fellowship stipend. I decided to stop by Dr. Bill Beckner's office to discuss some preliminary exam problems and mentioned that I could not get a hold of this particular reference book. Dr. Beckner pulled it from his shelf and told me that I could use his copy, but requested that I not bend the pages-one of his pet peeves. I was very happy to use the book and felt grateful that Dr. Beckner trusted me with his book. This gratitude only grew given that after I passed my preliminary exam, Dr. Beckner told me that I could keep the book because he had received another copy from the publisher. This kindness, along with the fact that I was really enjoying analysis and probability theory, helped cement my desire to have him as my dissertation advisor.

During that time, UT-Austin began the Emerging Scholars Program (ESP) in calculus, which was motivated and informed by the research work of Dr. Uri Treisman. ESP targeted students coming from historically underrepresented minority groups in mathematics-based disciplines just like me. It focused on academically capable students who could benefit from experiences to close academic gaps and enrich their understanding of mathematics. At a spring departmental picnic, Jackie Bacon, a fellow graduate student, spoke to me about her experiences teaching in ESP that first year of its inception. Fascinated by her comments and learning of the goals of ESP, I told her that I really wanted to teach in the program. I was eager to make a difference just like Dr. Treisman.

Working in ESP gave me the opportunity to develop my teaching and channel my creative energy. I worked with amazing students who came from similar backgrounds like mine. Two such students are Dr. Rey Rivera who is now President of Estrella Mountain Community College and Dr. Cristina Villalobos ${ }^{4}$ who is now a Professor of Mathematics and Associate Dean at the University of Texas Rio Grande Valley. My excitement in facilitating problemsolving sessions, seeing my students make deep connections in calculus tasks, and seeing them flourish gave me great joy. I often thought about creating opportunities for students to understand mathematical concepts deeplyopportunities I felt I lacked in my own background, as much more could have been asked of me.

As I taught in ESP, I continued my dissertation research in percolation theory, an area of statistical physics and mathematics that describes the behavior of connected clusters in a random graph. Problems in percolation theory are very simple to state, but extremely difficult to prove. The

\footnotetext{
${ }^{4}$ Dr. Cristina Villalobos is also featured in the book.
} 


\section{HISTORY}

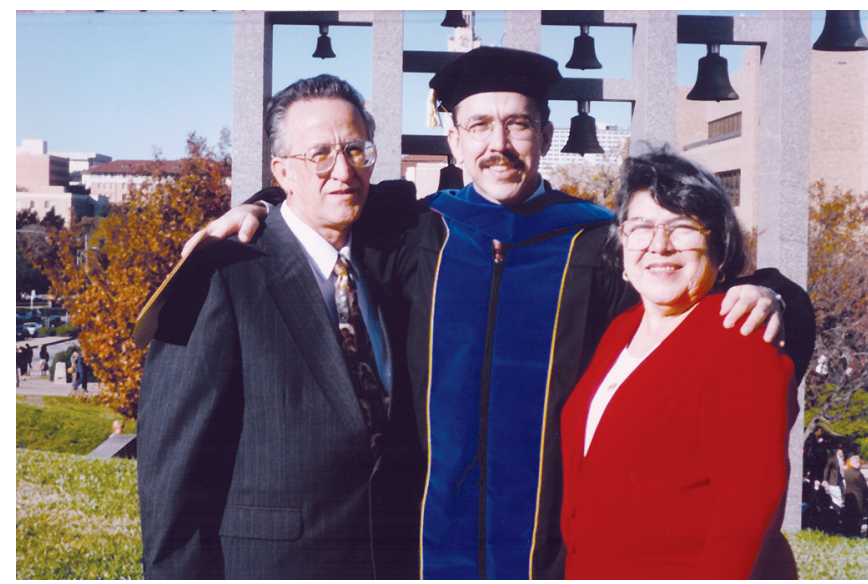

Figure 7. Picture with my parents during my $\mathrm{PhD}$ graduation in 1996.

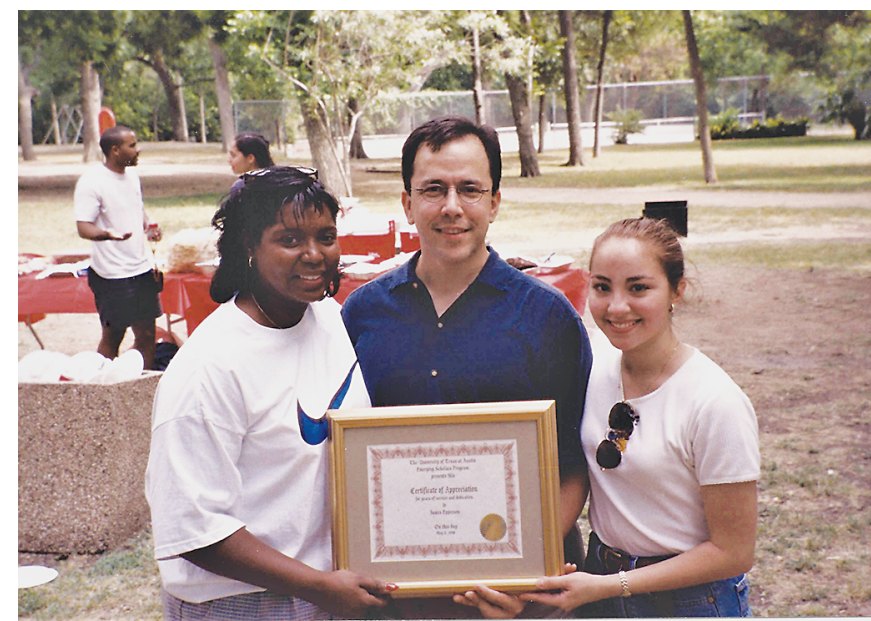

Figure 8. A picture of me in 1998 with the ESP staff when they presented me a certificate at the end of my postdoc for all my service to ESP.

independence required to conduct my research and the intensity of the research process left me feeling very isolated.

As a result, but perhaps not entirely, I became uninterested in my research and I began to dedicate more time to my ESP teaching. After just a year as a teaching assistant in the program, I was leading the annual instructor professional development workshop for faculty and graduate students who were running programs across the country. I also began giving presentations with Dr. Treisman about many aspects of ESP. For the second or third year of the UT-Austin training, I came up with types of mathematical problems and designed tasks for the worksheets used in the professional development of mathematics instructors.

Luckily, my $\mathrm{PhD}$ advisor allowed me to work on what I was interested in and gave me the independence to pursue my research while continuing my involvement with ESP. Yet, the continued feeling of isolation led me to realize that I was much more passionate about finding ways to provide deep mathematical learning experiences for students. This passion turned into a job. At the completion of my dissertation, Dr. Treisman offered me a postdoctoral fellowship at the Charles A. Dana Center for Mathematics and Science Education at UT-Austin.

Jumping at the chance to learn more from Dr. Treisman, I immersed myself in mathematics education. A major accomplishment while at the Dana Center was my work as one of the primary authors on the mathematics chapters of the Dana Center's and College Board's Mathematics Vertical Teams Toolkit. ${ }^{5}$ My work at the Dana Center also began my long involvement in various capacities with the Texas Essential Knowledge and Skills in Mathematics.

After completing my postdoctoral work I had a few job offers that would allow me to continue my research in percolation theory and mathematics education. But I decided that I could not split my commitment between mathematics research and mathematics education research. So, I accepted an attractive offer from the Department of Mathematics and Statistics at Texas Tech University. This position allowed me to take leadership in the Master of Arts program for teachers, offer graduate student assistant training, and conduct research in undergraduate mathematics education. This new opportunity led to my decision to become a mathematics education researcher.

\section{Current Life}

4.1. Professional career. Due to my abrupt change in direction after my $\mathrm{PhD}$, my mathematical research was limited to the research I conducted for my dissertation. In this work, I examined percolation on a randomized fractal using techniques from percolation theory, fractal geometry, and probability theory. I established threshold probabilities for determining when paths in the fractal would only be a local or surface effect versus one that would allow percolation through the structure.

My mathematics education research has been varied. In my early work, I focused on building the Master of Arts in Mathematics program for secondary mathematics teachers, after I moved from Texas Tech to UT-Arlington, and much of my energy focused on garnering funding to support the program. This led to creating an important resource for mathematics teacher educators entitled, "Strengthening and Supporting Standards-based Mathematics Teacher Preparation." Later, capitalizing on my early work on the 1998 Mathematical Vertical Teams Toolkit, which was disseminated nationwide for many years by the College

\footnotetext{
${ }^{5}$ J. Epperson, D. Holtzman, S. May, D. Sandow, and D. Stanley, Advanced Placement Program, Mathematics Vertical Teams Toolkit, The College Board and The Charles A. Dana Center, The University of Texas at Austin, New York, NY, 1998.
} 
Board, I was a co-principal investigator on a $\$ 3$ million GK-12 grant from the National Science Foundation (NSF). This grant allowed me to work with a high-needs school to develop graduate students' capacity to communicate and integrate their mathematics research into school curriculum. In partnership with teachers, this work vertically traced back key ideas and elements of our research to school-level mathematics where they were placed.

Almost simultaneously, I also received almost two million dollars in funding from the NSF as a co-principal investigator for the Arlington Undergraduate Research-based Achievement in STEM project. This project enabled creation of an Arlington Emerging Scholars Program in mathematics and chemistry whose focus was on broadening the reach of the more traditional Emerging Scholars Program model.

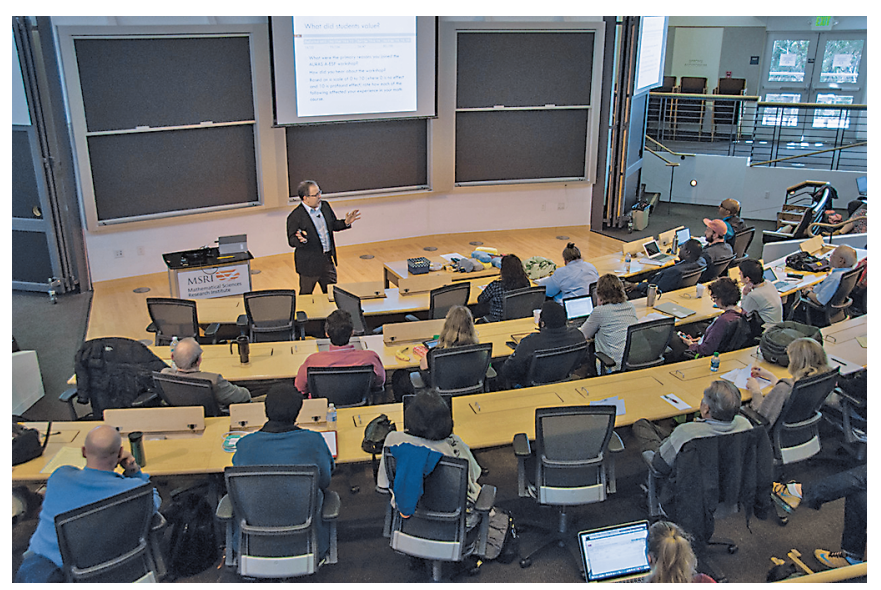

Figure 9. Presenting my work at the Mathematical Sciences Research Institute in 2017.

My more recent work involves mathematical problem solving and the development of mathematical knowledge for teaching. I have contributed as one of the lead authors of the Classroom Practices chapter of the Mathematical Association of America's (MAA) Instructional Practices Guide. ${ }^{6}$ My work as a co-principal investigator on the NSFfunded Mathematical Education of Teachers as an Application of Undergraduate Mathematics (META Math) project is laying the foundation for finding ways to integrate applications to mathematics teaching and explicit connections to school mathematics into mainstream mathematics courses for prospective secondary mathematics teachers.

I am grateful that my research and teaching have not gone unnoticed. I have been recognized six times with

${ }^{6}$ Martha Abell, Linda Braddy, Doug Ensley, Lew Ludwig, Hortensia SotoJohnson (editors), Instructional Practices Guide, Mathematical Association of America, Washington, DC, 2017. the UT-Arlington Provost's Research Excellence Award for my research and scholarship contributions. In March of 2020, I was selected as UT-Arlington's nominee for the Piper Professor Award, a statewide award given to only 10 professors across the state of Texas. Each university selects one nominee to move forward to the statewide competition. I have also been recognized for my teaching at many levels. This recognition includes the University of Texas System Regent's Excellence in Teaching Award, which carried a $\$ 30,000$ award, and an outstanding UT-Arlington Honors College Faculty Teaching Award in 2016. Because of my success as an educator, I carry the title of "Distinguished Teaching Professor" which is granted to faculty inducted into the Academy of Distinguished Teachers at UTArlington.

4.2. Family. As is often attributed to Latinx/Hispanic culture, my family is extremely important to me. I want to point out that my position at Texas Tech not only gave me a new professional opportunity, but in fact it is where I met my wife, Dr. Minerva Cordero, ${ }^{7}$ also a Latina mathematician. I love spending time with my family and traveling. Minerva and I love to dance, and we do so any chance we get. We now live in Arlington, Texas, close to my family and have raised two wonderful sons.

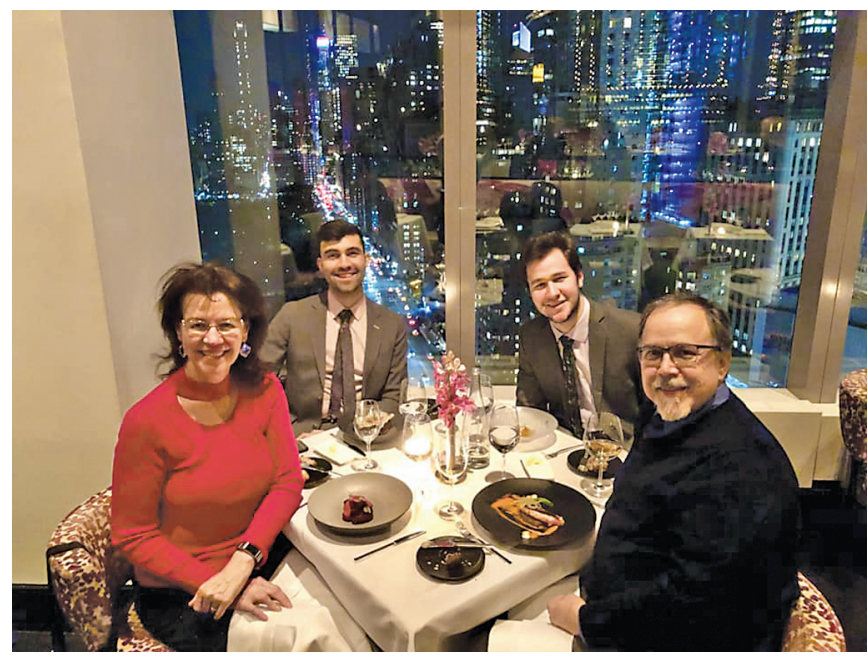

Figure 10. My wife, Minerva, and sons, Alex and Nicholas.

On a personal note, I enjoy music, singing, and watching international movies including Spanish-language novelas and miniseries. I am also an avid genealogist and I have traced my Mexican (e.g., Spanish, Mestizo, Mulato) ancestry in Mexico to the 1500s and further back to Spain to the 1300s. I believe my indigenous ancestry is mostly Chichimeca from San Luis Potosi, but I still have more work to do to verify this completely.

${ }^{7}$ Dr. Minerva Cordero is also featured in the book. 


\section{HISTORY}

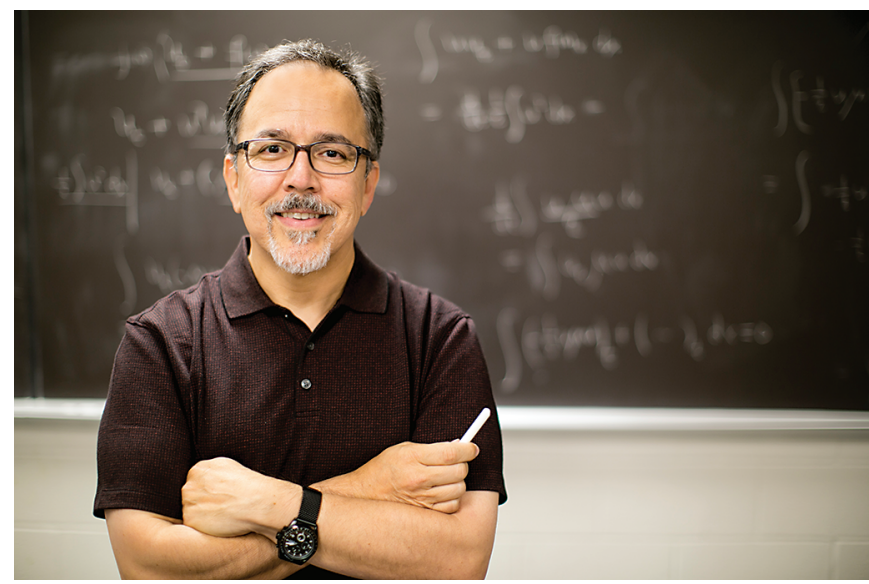

Figure 11. Dr. James A. Mendoza Álvarez.

\section{A View Toward the Future}

I believe the way for those outside the Latinx/Hispanic community to better support us is to strive to find common ground and aspirations that we can all agree upon.

What's the difference between a Latinx mathematics major and a non-Latinx major?

They may have been given very different messages about who can and can't do mathematics. It is our job to replace negative messages with authentic encouragement, support positive messages with excellent teaching and mentoring, and build upon successes by providing opportunities for advancement.

What's the same about a Latinx mathematics major and a non-Lantinx major?

They both love mathematics, and they chose mathematics because they identify as a "math person." Use this common ground. All majors need support and guidance. All majors should be given opportunities to further their mathematical interests. It is in making these equitable where strategies need to diverge. Negative stereotypes, unproductive classroom interactions, and shifting priorities unrelated to mathematics require us to reexamine how to provide the right support for Latinx majors that will enable them to take advantage of the same rich mathematical experiences provided to others. We need to reimagine ways that all students can flourish.
ACKNOWLEDGMENT. The artwork in Figure 1 was created by Ana Valle. The authors thank her for illustrating the portraits of the mathematicians featured in Testimonios.

\section{Credits}

Figure 1 is courtesy of Ana Valle.

Figures 2, 3, 5, 7, 8, and 10 are courtesy of James Álvarez. Figure 4 is courtesy of Olga M. Álvarez.

Figure 6 is courtesy of Mark Rudin.

Figure 9 is courtesy of David Eisenbud.

Figure 11 is courtesy of Dominique Anderson.

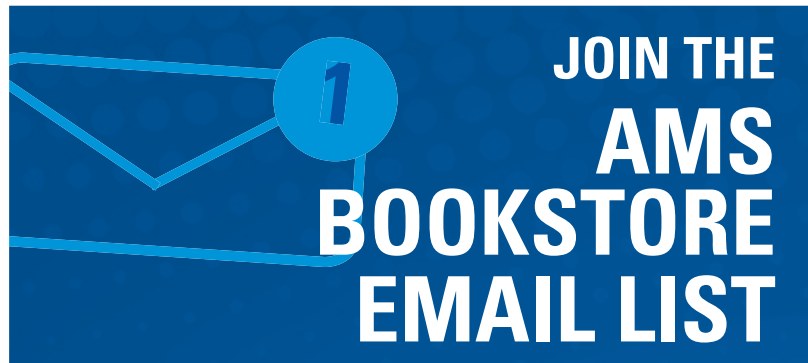

\section{Be the first to learn about:}

- Publishing highlights

- New titles being released

- Monthly sales

- Special discounts on AMS publications

SIGN UP AT ams.org/bookstore-email-list.

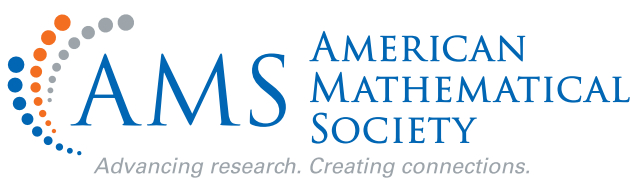

